\title{
Feeding Ecology of Stream-Dwelling Fishes from a Coastal Stream in the Southeast of Brazil
}

\author{
Rosana Mazzoni* and Leandro Damião Soares da Costa \\ Departamento de Ecologia, IBRAG; Universidade Estadual do Rio de Janeiro; São Francisco Xavier 524; \\ Maracanä; 20550-013; Rio de Janeiro - RJ - Brasil
}

\begin{abstract}
The relationship between ontogenetic variation of intestine length and feeding habits of five stream-dwelling fish species from the Ubatiba River were investigated. Analysed data were based on two size categories (juveniles and adults) and two food categories (animal and vegetal). Diet composition of each size category revealed that Astyanax janeiroensis and Geophagus brasiliensis changed food preference throughout ontogeny and switched from omnivorous/carnivorous to omnivorous/herbivorous and from omnivorous/carnivorous to omnivorous, respectively. These changes were followed by ontogenetic changes in the Intestinal Coefficient (IC). No ontogenetic differences were registered for IC and food categories consumed by Hoplias malabaricus but significant differences in the size of consumed preys as well as positive correlation between fish size (predator) and prey size was observed. Food items (within animal category) consumed by the adult Pimelodella lateristriga were mainly based on allochthonous arthropods whereas juvenile individuals fed with the same intensity on allochthonous and autochthonous arthropods; both juveniles and adult individuals of Mimagoniates microlepis were mainly allochthonous feeders. Mean IC values of Pimelodella lateristriga and Mimagoniates microlepis did not change along body growth. Although changes in food category consumption were not common among all the studied species, changes in the resource exploitation strategy was a rule among them, except for Mimagoniates microlepis.
\end{abstract}

Key words: Fish, coastal stream, feeding habit, intestinal coefficient

\section{INTRODUCTION}

Studies on fish feeding habits from Tropical environments have emphasised mainly descriptive data and temporal changes in the local feeding patterns. Very little attention has been given to the relationships between feeding habit and the structural adaptation of the digestive apparatus (Barbieri et al., 1994). Although diet composition of an individual is strongly determined by the resource availability, it has been frequently detected that feeding habits change with fish size and/or maturational stage (Wootton, 1990). Such changes are normally accompanied by morphological changes, switch between food types, and habitat exploitation (Wootton, 1990, Matthews, 1996).

Despite the above mentioned morphological and behavioural changes that follow fish development, many studies have clearly demonstrated that tropical fishes exploit a wide range of food items but, there is a pre-established limit of feeding variability related to structure and gastrointestinal duct length (Angelescu and Gneri, 1951; Fugi and Hahn, 1991; Lowe-McConnell, 1991).

In this study the relationship between ontogenetic variation of intestine length and diet of five

\footnotetext{
${ }^{*}$ Author for correspondence
} 
stream-dwelling fish species from the Ubatiba river was assessed. The choice of such species was based on the idea of having at least one species of each trophic guild, which is present in the study area. Studied species were: Hoplias malabaricus (Bloch, 1794), Mimagoniates microlepis (Steindachner, 1876), Geophagus brasiliensis (Quoy and Gaimard, 1824), Pimelodella lateristriga (Mueller and Troschel, 1849) and Astyanax janeiroensis Eigenmann, 1908.

\section{MATERIAL AND METHODS}

The Ubatiba River $\left(22^{\circ} 60^{\prime} \mathrm{S} ; 42^{\circ} 48^{\prime} \mathrm{W}\right)$ is a small coastal drainage in the oceanic slope of Serra do Mar in the State of Rio de Janeiro. Local water level is solely regulated by rainfall (c. $1500 \mathrm{~mm}$ year $^{-1}$ ) and run-off, with abundant summer (November - January) rain increasing water levels (Mazzoni and Lobón-Cerviá, 2000). Unpredictable spates (> $120 \mathrm{~mm} \mathrm{day}^{-1}$ ) are common throughout the year. The Ubatiba River ictiofauna is composed by twenty-two species (Mazzoni and Lobón-Cerviá, 2000) that, according to Bizerril (1994), comprises $7.4 \%$ of the total freshwater fish species from the Brazilian eastern rivers.

Physiographical description made at different localities along its horizontal gradient indicated a wide range of habitats; these and other physicochemical data were presented elsewhere (e.g. Costa, 1984; Mazzoni and Lobón-Cerviá, 2000). Riparian vegetation is composed of secondary Mata Atlântica in the upper stretches and herbs, shrubs and aquatic plants, in the lower part. Substrata vary according to water flow.

Fishes were collected in March 1999 through electrofishing $(220 \mathrm{v}, 1000 \mathrm{~W}, 2-3 \mathrm{~A})$, conditioned in ice for the transportation and processed to determine the standard length $(\mathrm{SL}, \mathrm{cm})$ and total weight (WT, gr). Gastrointestinal duct was removed through longitudinal abdominal incision, distended, measured (intestine length $=\mathrm{IL} ; \mathrm{cm}$ ) and conditioned in alcohol $\left(70^{\circ} \mathrm{GL}\right)$ for diet analysis. Diet composition was determined through the Frequency of Occurrence Method (Hynes, 1950) and food items were identified under stereomicroscopic to the lowest feasible taxonomical level. Intestinal Coefficient (IC) was determined for each individual, according to the model proposed by Hynes (1950): IC = IL / SL; where $\mathrm{IL}=$ intestine length and $\mathrm{SL}=$ standard length.
Specimens of each species were classified according to two size categories: (i) juveniles (SL $<\mathrm{SL}_{50} ; \mathrm{SL}_{50}=\mathrm{SL}$ of $1^{\text {st }}$ maturation) and (ii) adults $\left(\mathrm{SL}>\mathrm{SL}_{50}\right) . \mathrm{SL}_{50}$ of Astyanax, Geophagus, Mimagoniates and Pimelodella was established according to Mazzoni et al. (2005), Mazzoni and Iglesias-Rios (2002), Mazzoni (1998) and SoaresPorto (1991); $\mathrm{SL}_{50}$ of Hoplias was established according to the methodology proposed in Suzuki and Agostinho (1997). Therefore, IC was estimated for each specimen and mean specific IC was calculated for both size categories. In order to test the differences in the relative importance of animal and vegetal items in the diet of each size category, as well as ontogenetic differences in IC values, $\mathrm{t}$ tests (Zar, 1999) were applied.

\section{RESULTS}

A total of 243 specimens were analysed which included 33 Hoplias, 62 Pimelodella, 62 Astyanax, 55 Geophagus and 41 Mimagoniates. Results concerning the items consumed by each species (Table 1) indicate that a wide variability of items was used as food resource.

Considering the whole population of each studied species, Astyanax and Geophagus were generalists, feeding on animal and vegetal items, and should be classified as omnivorous; Hoplias, Mimagoniates and Pimelodella were carnivorous, and fish was the main food resource of the former (carnivorous / piscivorous) and allochthonous and autochthonous insects as the main food resource of the two latter species (carnivorous / insectivorous) (Table 2).

Diet composition of each size category, considering the main ecological food categories (animal and vegetal) registered as food resource for the studied species, revealed that Astyanax and Geophagus changed (t test; $\mathrm{p}<0.05$ - Table 2) food preference along ontogeny and switched from omnivorous / carnivorous (omnivorous species with higher frequency of animal items in the gut content) to omnivorous / herbivorous (omnivorous species with higher frequency of vegetal items in the gut content) and from omnivorous/carnivorous to omnivorous, respectively (Fig. 1). Ontogenetic analysis of Intestinal Coefficient (IC) corroborated the feeding patterns observed for the five studied species; mean IC of both size categories were significantly different only for Astyanax and Geophagus (t test; $\mathrm{p}<0.01$ - Table 3). 
Although no ontogenetic differences were registered for the food categories consumed by Hoplias, a detailed analysis of prey items, within the fish, anura and arthropod categories, revealed significant differences in the size of consumed preys (Table 4) as well as positive correlation between fish size and prey size (Fig. 2).

Table 1 - Food item registered in the gut content of the five studied fish species from the Ubatiba River. HM = Hoplias malabaricus, $\mathrm{PL}=$ Pimelodella lateristriga, AJ = Astyanax janeiroensis, $\mathrm{GB}=$ Geophagus brasiliensis, MM = Mimagoniates microlepis.

\begin{tabular}{|c|c|c|c|c|c|}
\hline 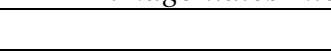 & HM & PL & $\mathbf{A J}$ & GB & MM \\
\hline \multicolumn{6}{|c|}{ Autocthonous Arthropoda } \\
\hline Crustacea & & $\mathrm{X}$ & $\mathrm{X}$ & $\mathrm{x}$ & \\
\hline Ephemeroptera larvae & & & $\mathrm{x}$ & $\mathrm{x}$ & $\mathrm{x}$ \\
\hline Diptera larvae & & & & $\mathrm{x}$ & \\
\hline Lepidoptera larvae & & & $\mathrm{x}$ & $\mathrm{x}$ & $\mathrm{x}$ \\
\hline Odonata Larvae & $\mathrm{x}$ & & $\mathrm{x}$ & $\mathrm{x}$ & $\mathrm{x}$ \\
\hline \multicolumn{6}{|c|}{ Allocthonous Arthropoda } \\
\hline Acarina & & $\mathrm{x}$ & & $\mathrm{x}$ & $\mathrm{x}$ \\
\hline Arachnidae & & & & $\mathrm{x}$ & $\mathrm{x}$ \\
\hline Coleoptera & & $\mathrm{X}$ & $\mathrm{x}$ & & $\mathrm{x}$ \\
\hline Diptera & & & & & \\
\hline Hymenoptera & & $\mathrm{x}$ & $\mathrm{x}$ & & $\mathrm{x}$ \\
\hline Orthoptera & $\mathrm{x}$ & & $\mathrm{x}$ & & \\
\hline \multicolumn{6}{|c|}{ MOLUSCS } \\
\hline Bivalves & & & & $\mathrm{x}$ & \\
\hline Gastropods & & & $\mathrm{x}$ & $\mathrm{x}$ & \\
\hline \multicolumn{6}{|c|}{ ANPHIBIANS } \\
\hline Anura & $\mathrm{x}$ & & & & \\
\hline \multicolumn{6}{|c|}{ FISH } \\
\hline M. microlepis & $\mathrm{x}$ & & & & \\
\hline A. janeiroensis & $\mathrm{x}$ & & & & \\
\hline G. brasiliensis & $\mathrm{x}$ & & & & \\
\hline$P$. vivipara & $\mathrm{x}$ & & & & \\
\hline \multicolumn{6}{|c|}{ FISH SCALES } \\
\hline Cycloid scales & & & $\mathrm{x}$ & $\mathrm{x}$ & \\
\hline \multicolumn{6}{|c|}{ VEGETALS } \\
\hline Filamentous algae & & & $\mathrm{x}$ & & \\
\hline Leafs & & & $\mathrm{x}$ & & \\
\hline Vegetal fragments & & & & $\mathrm{x}$ & \\
\hline Seeds & & & $\mathrm{x}$ & $\mathrm{x}$ & \\
\hline
\end{tabular}

Feeding preference of young individuals were based on smaller preys (prey body length between $0.1 \mathrm{~cm}$ to $1.9 \mathrm{~cm}$ ) whereas adult individuals preferred larger ones (prey body length $>2.0 \mathrm{~cm}$ ) (Table 4). In the same rationale, it was also observed that food items (within animal category) consumed by the adult
Pimelodella were mainly based on allochthonous arthropods, whereas juvenile individuals fed with the same intensity on allochthonous and autochthonous arthropods (Fig. 3A). Both, juveniles and adult individuals of Mimagoniates were mainly allochthonous feeders (Fig. 3B). 
Table 2 - Trophic categories and frequency of occurrence (FO), recorded in the gut content of the five studied fish species from the Ubatiba River. HM = Hoplias malabaricus, PL = Pimelodella lateristriga, AJ = Astyanax janeiroensis, $\mathrm{GB}=$ Geophagus brasiliensis, $\mathrm{MM}=$ Mimagoniates microlepis. $1=$ young individuals; $2=$ adult individuals; $\mathrm{n}=$ number of fish with gut content; $\mathrm{X}^{2}=$ Qui-squared value; $\mathrm{P}=$ level of significance.

\begin{tabular}{|c|c|c|c|c|c|c|c|c|c|c|}
\hline & $\begin{array}{l}\text { HM 1 } \\
n=16\end{array}$ & $\begin{array}{l}\text { HM } 2 \\
n=17\end{array}$ & $\begin{array}{l}\text { PL 1 } \\
n=29\end{array}$ & $\begin{array}{l}\text { PL 2 } \\
n=23\end{array}$ & $\begin{array}{l}\text { AJ } 1 \\
n=33\end{array}$ & $\begin{array}{l}\text { AJ } 2 \\
n=29\end{array}$ & $\begin{array}{l}\text { GB 1 } \\
\mathbf{n}=27\end{array}$ & $\begin{array}{l}\text { GB } 2 \\
n=28\end{array}$ & $\begin{array}{c}\text { MM 1 } \\
n=19\end{array}$ & $\begin{array}{c}\text { MM 2 } \\
n=22\end{array}$ \\
\hline Autocthonous & 37.5 & & 62.1 & 100.0 & 100.0 & 62.1 & 51.9 & 96.4 & 52.6 & 50.0 \\
\hline Arthropoda & & & & & & & & & & \\
\hline Allocthonous Arthropoda & 18.8 & & 58.6 & 60.9 & 63.6 & 37.9 & 29.6 & 53.6 & 93.1 & 89.4 \\
\hline Moluscs & & & & & & 72.4 & 100.0 & 25.9 & & \\
\hline Anura & & 35.3 & & & & & & & & \\
\hline Fish & 100.0 & 100.0 & & & & & & & & \\
\hline Fish Scales & & & & & 66.7 & 72.4 & 22.2 & 42.9 & & \\
\hline Animal items (mean FO) & 52.1 & 67.7 & 60.3 & 80.4 & 81.8 & 57.5 & 60.5 & 58.6 & 72.9 & 69.7 \\
\hline Vegetal parts & & & & & & 65.5 & 18.0 & 37.0 & & \\
\hline Seeds & & & & 61.5 & 33.3 & 65.5 & 40.7 & 78.6 & & \\
\hline Vegetal Items (mean FO) & & & & & 33.3 & 65.5 & 29.4 & 57.8 & 0.0 & 0.0 \\
\hline$X^{2}$ & 52.08 & 67.65 & 60.34 & 80.43 & 17.12 & 0.15 & 5.77 & 0.09 & 72.90 & 69.70 \\
\hline $\mathrm{P}$ & $0.01 *$ & $0.01 *$ & $0.01 *$ & $0.01 *$ & $0.01 *$ & 0.70 & $0.01 *$ & 0.77 & $0.01 *$ & $0.01 *$ \\
\hline
\end{tabular}

Table 3. Mean values of intestinal coefficient (IC) of young and adult individuals; significance levels (p) of differences of IC between adult and young specimens ( $t$ test).

\begin{tabular}{lcccc}
\hline Species & $\begin{array}{c}\text { IC } \\
\text { young }\end{array}$ & $\begin{array}{c}\text { IC } \\
\text { adult }\end{array}$ & \multicolumn{1}{c}{ t test } \\
\hline & Mean & Mean & $\mathrm{t}$ & $\mathrm{p}$ \\
\hline H. malabaricus & 0.59 & 0.53 & 0.88 & 0.396 \\
P. lateristriga & 0.43 & 0.53 & -2.06 & 0.052 \\
A. janeiroensis & 0.64 & 0.84 & 5.45 & $<0.001$ \\
G. brasiliensis & 0.87 & 0.98 & -3.94 & $<0.001$ \\
M. microlepsis & 0.44 & 0.45 & -0.06 & 0.530 \\
\hline
\end{tabular}

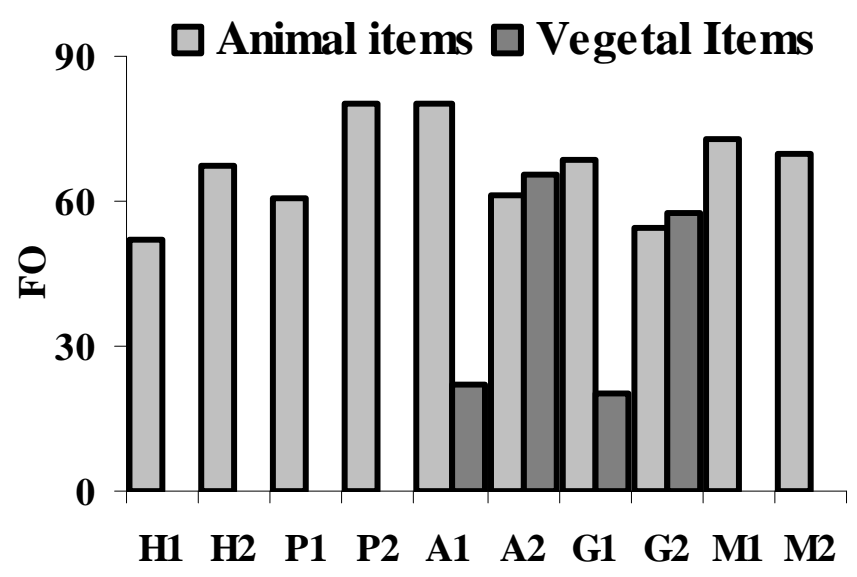

Figure 1 - Frequency of Occurrence (FO) of consumed items of young (H1, P1, A1, G1, M1) and adult individuals (H2, P2, A2, G2, M2) of the five studied species. 


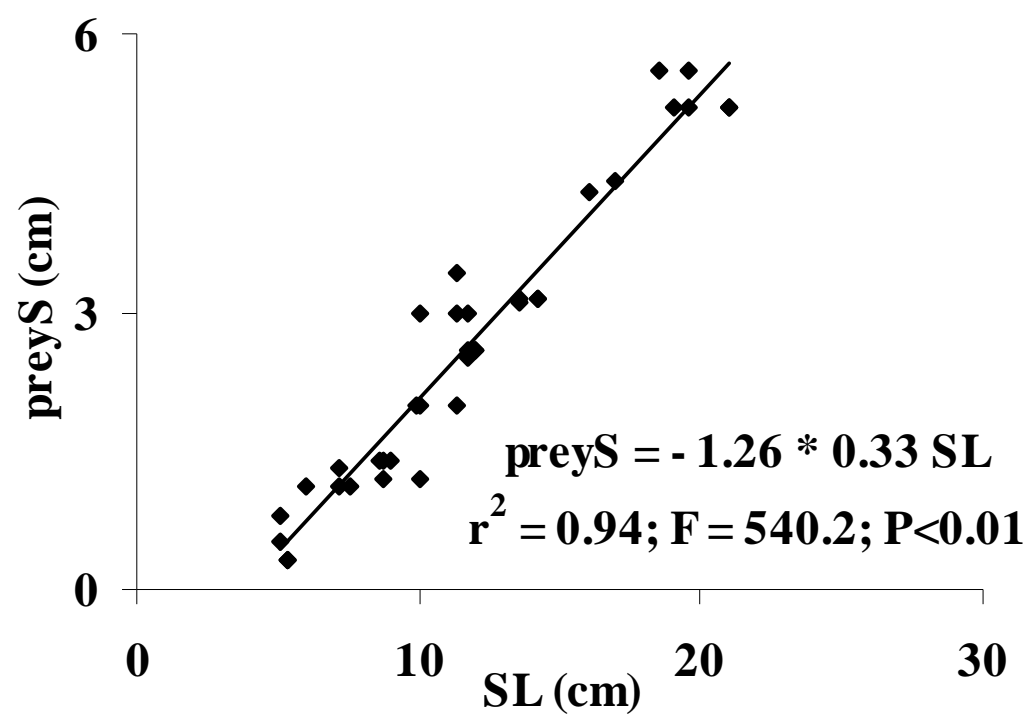

Figure 2 - Relationship between Hoplias malabaricus Standard length (SL) and prey size (PreyS).

Table 4 - Frequency of Occurrence (FO) of food items and respective sizes (prey size) in the diet of young and adult individuals of Hoplias malabaricus. $\mathrm{t}=\mathrm{t}$ test value; $\mathrm{P}=$ significance level; $*$ significant case.

\begin{tabular}{|c|c|c|}
\hline Food Item & FO young & FO adult \\
\hline \multicolumn{3}{|c|}{ Prey $>2.0 \mathrm{~cm}$} \\
\hline A. janeiroensis (Fish) & 16.7 & 47.1 \\
\hline G. brasiliensis (Fish) & 16.7 & 35.3 \\
\hline Anura & 0.0 & 35.3 \\
\hline Mean FO & 11.1 & 39.2 \\
\hline $\mathrm{t}$ & \multicolumn{2}{|r|}{4.12} \\
\hline $\mathrm{P}$ & \multicolumn{2}{|r|}{$0.014 *$} \\
\hline \multicolumn{3}{|c|}{ Prey $<2.0 \mathrm{~cm}$} \\
\hline M. microlepis (Fish) & 16.7 & 35.3 \\
\hline P. vivipara (Fish) & 37.5 & 16.7 \\
\hline Diptera & 37.5 & 0.0 \\
\hline Odonata & 37.5 & 0.0 \\
\hline Orthoptera & 37.5 & 0.0 \\
\hline Mean FO & 33.3 & 10.4 \\
\hline $\mathrm{t}$ & \multirow{2}{*}{\multicolumn{2}{|c|}{$\begin{array}{c}2.81 \\
0.022^{*}\end{array}$}} \\
\hline $\mathrm{P}$ & & \\
\hline
\end{tabular}



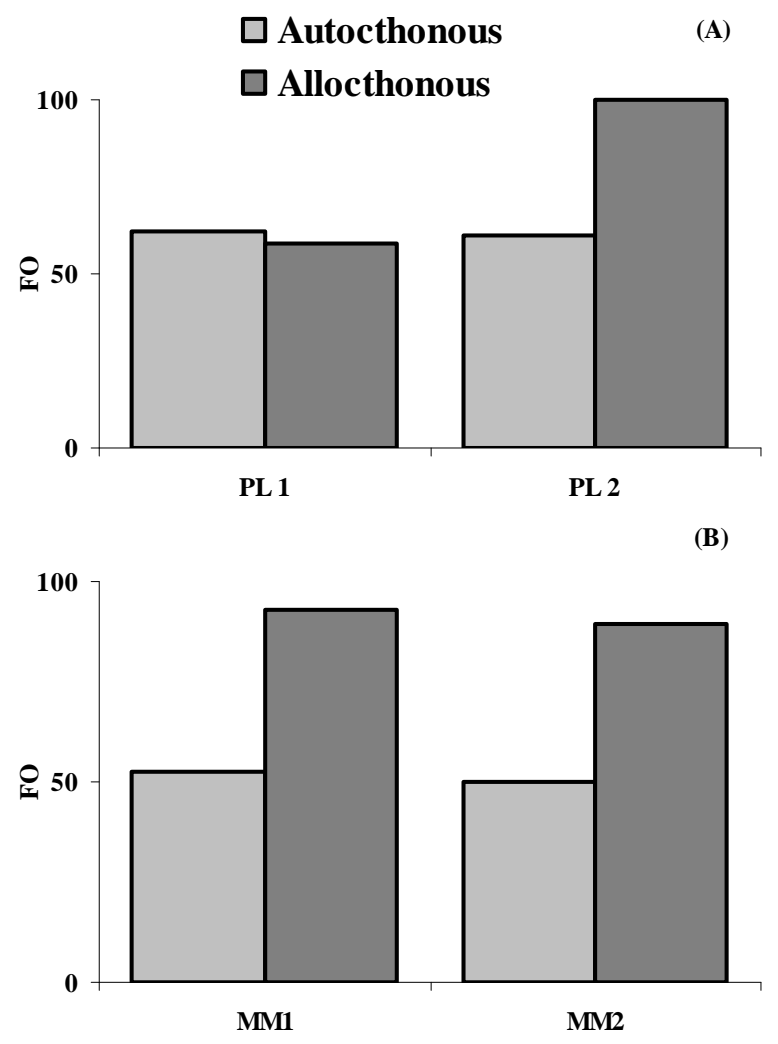

Figure 3 - Frequency of Occurrence of allochthonous and autochthonous arthropods recorded in the gut content of young (PL1) and adult (PL2) P. lateristriga (A) and young (MM1) and adult (MM2) M. microlepis (B).

\section{DISCUSSION}

As fish grow they show changes in their diet and susceptibility to predation, and these ontogenetic changes are probably central to an understanding of the ecology of fishes (Wootton, 1990). In the present study ontogenetic changes were detected in the feeding patterns of five stream-dwelling fish species from a coastal stream in the Brazilian East basin. With the empirical limitations related to the Frequency of Occurrence method for fish diet analysis, the present results reflect the feeding patterns of these species. This analysis revealed that only Astyanax and Geophagus changed the relative importance of food categories (animal versus vegetal) during the growth. The other three species were conservative. Otherwise, they exploited a wide range of food items and, in some cases, switched among items within the same food category.

Diet composition of Geophagus was in accordance with an omnivorous feeding behaviour, corroborated by the registered IC values (IC between 0.69 and 1.11), as the mean IC values of omnivorous species were 1.34 (Barbieri et al., 1994). Similar results were posted by Sabino and Castro (1990) and Uieda (1995). Nevertheless, the relative importance of animal vs. plant items in the diet of juvenile $v s$ adult individuals showed marked changes in the feeding behaviour during the growth. The pattern expected in the omnivorous species (Wootton, 1990), was met in the juveniles that foraged actively on animal items, whereas adult individuals did not show differences in the relative contribution of animal $v s$. plant items.

Similar to Geophagus, Astyanax showed an omnivorous diet (IC between 0.64 and 1.00). Astyanax fed mainly on autochthonous items. However, several studies on Tetragonopterinae species have indicated that such species were essentially omnivorous, preferring allochthonous items (Barbieri et al., 1994; Castro and Casatti, 1997; Casatti, 2002). Luiz et al. (1998) found that 
A. bimaculatus from the Paraná basin were herbivorous. In addition, Mazzoni (pers. obs.) recorded Poecilia vivipara in the gut of one individual of Astyanax Such contrasting results indicated that Astyanax presented a wide range of feeding tactics and hence, it should be classified as opportunistic feeders (Vilella et al., 2002; Motta \& Uieda, 2004; Bennemann et al., 2005). Comparing food content of juveniles $v s$. adult individuals of Astyanax, a significant switch from omnivorous/ carnivorous to omnivorous/ herbivorous during ontogenetic development was noticed. According to Wootton (1990), the first year of life in fish is a time period of intense increment in body size and, among omnivorous species is hardly expected the decrease in the relative participation of animal items in the diet of adult individuals.

Juvenile Hoplias was considered carnivorous/ insectivorous switching to carnivorous/ piscivorous after the first maturity. This mean that feeding was exclusively based on animal items as proposed by Castro and Casatti (1997) when studying Pardo River fishes. Plant items have also been reported (e.g. Caramaschi, 1979; Luiz et al., 1998). Despite the conservative feeding of Hoplias in Ubatiba River, it was observed that during the juvenile period prey size increased, as Hoplias increased in size. Caramaschi (1979) found that $<12 \mathrm{~cm}$ individuals fed upon arthropods and fishes beyond that size the consumption of fish increased markedly. This could be a competitive avoidance strategy as arthropods were the most used food resource by all the species in the fish assemblage studied. Nonetheless, Wootton (1990) suggested that most changes that fishes experienced during growth were probably accounted for by morphological and maturational changes, particularly by the increments in mouth size and improvement in locomotory ability. Supporting evidences for the allometric trends for the sizerelated relationships between predator and prey were available for a variety of animals (Wilson, 1975), and a widely recorded pattern concerned to the positive relations between predator and prey body size. Despite of these evidences, many exceptions has been presented, but quantitative treatment was scarce and must be empirically improved (Peters, 1983).

Mimagoniates diet was exclusively based on arthropods, with high participation of allochthonous Diptera and Hymenoptera. No differences were found for the food items consumed by the young and adult individuals, hence both were classified as carnivorous/insectivorous with mean IC of 0.45 that was in accordance with Barbieri et al. (1994). The preference for the organisms that fall in the water and are snapped in the surface is a high specialised feeding strategy (Costa, 1987; Sabino and Castro, 1990; Mazzoni and Iglesias-Rios, 2002) and should explain the absence of differences in the food items consumed by young and adult individuals.

The predominance of allochthonous and autochthonous insects and larvae plus sand, mica and quartz fragments together with a depressed dorso-ventral shape suggested that individuals of $P$. lateristriga were benthonic feeders. These results were corroborated by Soares-Porto (1994), Castro and Casatti (1997), Luiz et al. (1998) and Castro et al. (2003) while studying feeding ecology of Pimelodella species. Nonetheless, the predominance of allochthonous items among adult individuals indicated an epibenthonic behaviour that had been demonstrated by quantitative studies about micro-habitat use (unpublished data), and the improvement of locomotory ability related to the maturational development mentioned by Wootton (1990).

Concerning the diet comparison between the adults and juveniles of $P$. lateristriga, no significant differences were found; both young and adults were insectivorous getting the food items from the benthos. Mean IC was 0.51, varying from 0.36 to 0.59 without significant differences between the adult and juveniles specimens; such range of IC variation was in accordance to a carnivorous behaviour proposed by Barbieri et al. (1994).

Based on diet and IC of the five studied species, the following classification could be proposed: $H$. malabaricus - Carnivorous Piscivorous, $M$. microlepis - Carnivorous / Insectivorous, $P$. lateristriga - Carnivorous / Insectivorous, all of then without IC and diet variation along ontogeny; G. brasiliensis - Omnivorous and A. janeiroensis Omnivorous, both with IC and diet variation along ontogeny. Although changes in food category consumption were not common among all the studied species, changes in the resource exploitation strategy was a rule among them, except for M. microlepis. Hence, M. microlepis was a conservative species in feeding strategy and changes in the foraging strategies of the other four species should be accounted for the morphological and maturational changes, particularly in the 
improvement in exploratory and/or locomotory ability.

\section{AKNOWLEGDMENTS}

We thank the members of Laboratório de Ecologia de Peixes from the Universidade do Estado do Rio de Janeiro for helping in the field work. Erica Pellegrini Caramaschi and Ricardo Iglesias Rios for the valuable comments on an earlier draft. To Chiara Mazzoni for the English revision. This wok is part of the Scientific Initiation (PIBIC/CNPq) study of the junior author and was granted by FAPERJ / APQ1 / E-26/171.555-00 and CNPq / APQ-47942601-5 and by an individual grant to the senior author CNPq 302628/2002-9.

\section{RESUMO}

Foi investigada a relação entre as variações ontogenéticas do comprimento do intestino e os hábitos alimentares de cinco espécies de peixes do rio Ubatiba, RJ. Os dados analisados foram baseados em duas categorias de tamanho (jovens e adultos) de cada espécie e duas categorias de alimento (animal e vegetal). A composição da dieta de cada categoria de tamanho revelou que Astyanax janeiroensis e Geophagus brasiliensis mudaram a preferência alimentar ao longo do desenvolvimento ontogenético e alternaram entre onívoros / carnívoros para onívoros / herbívoros e entre onívoros / carnívoros para onívoros, respectivamente; essas alterações foram acompanhadas por alterações ontogenéticas do Coeficiente Intestinal (CI). Não foram registradas diferenças relacionadas à ontogenia tanto para o CI como para as categorias de alimento consumidas por Hoplias malabaricus mas, dentro da categoria animal, foram observadas diferenças significativas para o tamanho das presas consumidas, bem como correlação positiva entre o tamanho do peixe (predador) e o tamanho da presa. Foi ainda observado que os itens alimentares (dentro da categoria animal) consumidos pelos adultos de Pimelodella lateristriga foram principalmente baseados em artrópodes alóctones, enquanto os jovens consumiram na mesma intensidade artrópodes alóctones e autóctones; tanto os jovens como os adultos de Mimagoniates microlepis se alimentaram principalmente de artrópodes alóctones. Os valores médios do CI de $P$. lateristriga e M. microlepis não variaram ao longo do crescimento do corpo. Apesar do consumo das diferentes categorias tróficas não ter sido registrado para todas as espécies estudadas, as alterações da estratégia de exploração dos recursos foi a regra entre essas espécies, exceto para $M$. microlepis. Dessa forma, sugerimos que $M$. microlepis é uma espécie conservadora, no que se refere a estratégia de forrageamento e que as alterações nas estratégias tróficas das outras quatro espécies podem ser explicadas pelas alterações morfológicas e maturacionais, particularmente pela habilidade na capacidade exploratória e/ou locomotora.

\section{REFERENCES}

Angelescu, V. and Gneri, F. S. (1951), Adaptaciones del aparato digestivo al régimen alimenticio en alguns peces del rio de rio Uruguay e de rio de La Plata. Revista del Instituto de Investigaciones del Museu Argentino de Ciencias Naturales, 1-122.

Barbieri, G., Peret, A. C. and Verani, J. R. (1994), Notas sobre a adaptação do trato digestivo ao regime alimentar em espécies de peixes da região de São Carlos (SP) I. Quociente Intestinal. Revista Brasileira de Biologia, 54, 63-69.

Benemann, S. T., Gealh, A. M., Orsi, M. L. and Souza, L. M. (2005), Ocorrência e ecologia trófica de quatro espécies de Astyanax (Characidae) em diferentes rios da bacia do rio Tibagi, Paraná, Brasil. Iheringia, ser. Zool, 95, 247-254.

Bizerril, C. R. S. F. (1994), Análise taxonômica e biogeográfica da ictiofauna de água doce do leste brasileiro. Acta Leopoldensia, 16, 51-80.

Caramaschi, E. M. P. (1979), Reprodução $e$ Alimentação de Hoplias malabaricus (Bloch, 1794) na represa do rio Pardo (Botucatu, SP). Master Thesis, UFSCar, São Carlos, 144p.

Castro, R. M. C. and Casatti, L. (1997), The fish fauna from a small forest stream of the Paraná river Basin, southeastern Brazil. Ichthyogical Explorations of Freshwaters, 7, 337-352.

Castro, R. M. C., Casatti, L., Santos, H. F., Ferreira, K. M., Ribeiro, A. C., Benine, R. C., Dardis, G. Z. P., Melo, A. L. A., Stopiglia, R., Abreu, T. X., Bockmann, F. A., Carvalho, M., Gibran, F. Z. and Lima, F. C. T. (2003), Estrutura e composição da ictiofauna de riachos do rio Paranapanema, sudeste e sul do Brasil. Biota Neotropica, 3, http // biotaneotropica.org.br / v3n1 / pt / abstract?article+BN01703012003. 
Casatti, L. (2002), Alimentação dos peixes em um riacho do Parque Estadual Morro do Diabo, bacia do Alto Rio Paraná, sudeste do Brasil. Biota Neotropica, 2.

Costa, W. J. E. M. (1984), Peixes fluviais do sistema lagunar de Maricá, Rio de Janeiro, Brasil. Revista Atlântica, 7, 65-72.

Costa, W. J. E. M. (1987), Feeding habits of a fish community in a Tropical coastal stream, rio Mato Grosso, Brasil. Studies on Neotropical Fauna and Environment, 22, 145-153.

Fugi, R. and Hahn, N. S. (1991), Espectro alimentar e relações morfológicas com o aparelho digestivo de três espécies de peixes comedores de fundo do rio Paraná, Brasil. Revista Brasileira de Biologia, 51, 873-879

Hynes, H. B. N. (1950), The food of freshwater stickle backs (Gasteroteus aculeatus and Pygosteus pungitius), with a review of methods used in studies of the food of fishes. Journal of Animal Ecology, 19, 35-58.

Lowe-McConnell, R. H. (1991), Ecological studies in tropical fish communities. Cambridge: Cambridge University Press.

Luiz, E. A., Agostinho, A. A. and Gomes, L.C. (1998), Ecologia trófica de peixes em dois riachos da bacia do rio Paraná. Revista Brasileira de Biologia, 58, 273-285.

Matthews, W. J. (1996), Patterns in freshwater fish ecology. New York: Chapman \& Hall.

Mazzoni, R. (1998), Estrutura das Comunidades e Produção de Peixes de um Sistema Fluvial Costeiro da Mata Atlântica, Rio de Janeiro. PhD Thesis, UFSCar, São Carlos, 96p.

Mazzoni, R. and Lobón-Cerviá, J. (2000), Longitudinal structure, density and production rates of a Neotropical stream fish assemblage: the river Ubatiba in the Serra do Mar, southeast Brazil. Ecography, 23, 588-602.

Mazzoni, R. and Iglesias-Rios, R. (2002), Distribution pattern of two fish species in a coastal stream in the Southeast of Brazil. Brazilian Journal of Biology, 62, 171-178.

Mazzoni, R., Mendonça, R. S. and Caramaschi, E. P. (2005), Reproductive biology Astyanax janeiroensis (Osteichthyes, Characidae) from the Ubatiba River, Maricá, RJ, Brazil. Brazilian Journal of Biology, 65, 643-649.

Mazzoni, R., Fenerich-Verani, N., Caramaschi, E. P. and Iglesias-Rios, R. (2006), Stream-dwelling fish communities from an Atlantic rain forest drainage. Brazilian Archives of Biology and Technology, 49, 249-256.

Motta, R. L. and Uieda, V. S. (2004), Dieta de duas espécies de peixes do ribeirão do Atalho, Itatinga, SP. Revista Brasileira de Zoociências, 6, 191-205.
Peters, R. H. (1985), The ecological implications of body size. The Journal of Applied Ecology, 22, 291292.

Soares-Porto, L. M. (1991), Distribuição longitudinal, Dieta alimentar e Ciclo reprodutivo de Pimelodella lateristriga (Osteichthyes, Siluroidei) no rio Ubatiba, Maricá, Rio de Janeiro. Master Thesis, UFRJ/MNRJ, Rio de Janeiro, $101 \mathrm{p}$.

Soares-Porto, L. M. (1994), Dieta e ciclo diurno de atividade alimentar de Pimelodella lateristriga (Osteichthyes, Siluroidei) no rio Ubatiba, Maricá, Rio de Janeiro. Revista Brasileira de Biologia, 54, 451458.

Sabino, J. and Castro, R. M. C. (1990), Alimentação, período de atividade e distribuição espacial dos peixes de um riacho da floresta Atlântica (sudeste do Brasil). Revista Brasileira de Biologia, 50, 23-36.

Suzuki, H. I. and Agostinho, A. A. (1997), Reprodução de peixes do reservatório de segredo. In: A. A. Agostinho and L. C. Gomes (eds.). Reservatório de Segredo, Bases Ecológicas para o Manejo. Maringá: Editora da UEM. pp. 163-181.

Uieda, V. S. (1995), Comunidade de Peixes de um Riacho Litorâneo: Composição, Habitat e Hábitos. PhD Thesis, UNICAMP, Campinas, 229p.

Vilella, F. S., Becker, F. G. and Hartz, S. M. (2002), Diet of Astyanax species (Teleostei, Characidae) in an Atlantic forest river in Southern Brazil. Brazilian Archives of Biology and Technology, 45, 223-232.

Wilson, D. S. (1975), The adequacy of body size as a niche difference. American Naturalist, 109, 769-784.

Wootton, R. J. (1990), Ecology of Teleost Fishes. London: Chapman \& Hall.

Zar, J. H. (1999), Biostatistical Analysis. New Jersey: Prentice-Hall.
Received: September 30, 2005; Revised: May 08, 2006; Accepted: March 15, 2007. 
PÁGINA

EM

BRANCO 